\title{
Strong bond cleavage promoted by silyl group migration in a coordination sphere
}

\author{
H. Nakazawa \\ Department of Chemistry, Graduate School of Science, \\ Osaka City University, Sumiyoshi-ku, Japan
}

\begin{abstract}
$\mathrm{C}-\mathrm{CN}$ bond cleavage in organonitriles was attained in the photoreaction with $\mathrm{HSiEt}_{3}$ in the presence of a catalytic amount of $\left(\eta^{5}-\mathrm{C}_{5} \mathrm{H}_{5}\right) \mathrm{Fe}(\mathrm{CO})_{2} \mathrm{Me}$. The reaction sequence was proposed, where silyl migration from $\mathrm{Fe}$ to $\mathrm{N}$ in the coordinating nitrile is a key step. DFT calculations proposed a silyl migration with small activation energy of $4.0 \mathrm{kcal} / \mathrm{mol}$ and subsequent $\mathrm{C}-\mathrm{CN}$ bond cleavage on the $\mathrm{Fe}$ coordination sphere. $\mathrm{N}-\mathrm{CN}$ bond cleavage in cyanamide $\left(\mathrm{R}_{2} \mathrm{NCN}\right)$ was also attained by a transition metal catalyst. A catalytic cycle was proposed where a silyl migration from a transition metal to the nitrile nitrogen is involved. An $\mathrm{N}$-silylated $\eta^{2}$-amidino complex was isolated, which was shown to be an intermediate in the catalytic pathway.

Keywords: $C-C$ bond cleavage, $C-N$ bond cleavage, transition metal catalysis, silyl migration.
\end{abstract}

\section{Introduction}

Investigations of selective bond cleavage as well as selective bond formation of chemical compounds is important from the viewpoint of atom efficiency, low environmental load, and sustainable chemistry. Weak bond cleavage is not so difficult, whereas strong bond cleavage with keeping weak bonds intact is quite difficult. Therefore, selective strong bond cleavage is a challenging topic in chemistry. One of the promising ways to overcome the difficulties is using a transition metal catalyst.

As the carbon-carbon bond is relatively unreactive, $\mathrm{C}-\mathrm{C}$ bond cleavage is an area of considerable current interest [1]. In particular, $\mathrm{C}-\mathrm{C}$ bond activation in 
acetonitrile is difficult because it has rather strong $\mathrm{C}-\mathrm{C}$ bond energy (133 kcal $\mathrm{mol}^{-1}$ ) compared with alkane C-C bond energy ( $c$ a. $\left.83 \mathrm{kcal} \mathrm{mol}^{-1}\right)$.

Transition metal complexes have been used to attain $\mathrm{C}-\mathrm{C}$ bond cleavage of nitrile. They mainly involve Group 10 transition metal triads [2-10]. In addition, one example for Mo [11], Co [12], U [13], and two examples of $\mathrm{Cu}$ $[14,15]$ have been reported. These reactions show stoichiometric $\mathrm{C}-\mathrm{C}$ bond cleavage. In contrast, a few catalytic reactions involving $\mathrm{Ni}$ [16] and $\mathrm{Pd}$ [17] complexes have been reported. For these examples, it is proposed or clearly shown that a direct oxidative addition of a C-CN bond toward an electronically unsaturated transition metal fragment takes place to give an alkyl(aryl)-cyano complex (eq. (1)).

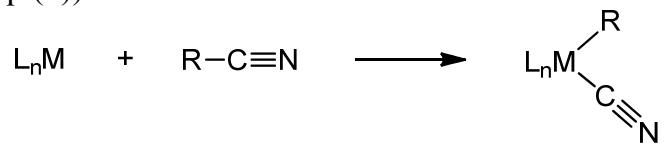

This article introduces a new reaction pathway for organonitrile $\mathrm{C}-\mathrm{C}$ bond cleavage where silyl group migration from a transition metal to nitrile nitrogen in the coordination sphere is a key step [18-20]. This article also report silyl assisted N-CN bond cleavage of cyanamide [21].

\section{Stoichiometric C-CN bond cleavage of acetonitrile by a silyl-iron complex}

Photoreaction with a 400-W medium pressure mercury arc lamp (pyrex filtered) of a THF solution containing $\mathrm{CpFe}(\mathrm{CO})_{2}\left(\mathrm{SiMe}_{3}\right), \mathrm{MeCN}$, and 2 equiv of $\mathrm{P}\left(\mathrm{NMeCH}_{2}\right)_{2}(\mathrm{OMe}) \quad(\mathrm{L})$ generated $\mathrm{CpFe}(\mathrm{CO}) \mathrm{L}\left(\mathrm{SiMe}_{3}\right) \quad(25 \%$ yield $)$, $\mathrm{CpFe}(\mathrm{CO}) \mathrm{L}(\mathrm{Me})\left(6 \%\right.$ yield), $\mathrm{CpFeL}_{2}(\mathrm{Me})(15 \%$ yield $), \mathrm{CpFeL}_{2}(\mathrm{CN}) \quad(19 \%$ yield), and $\mathrm{Me}_{3} \mathrm{SiCN}$ (66\% yield) (eq. (2)). When $\mathrm{CD}_{3} \mathrm{CN}$ was used in place of $\mathrm{CH}_{3} \mathrm{CN}$, the corresponding $\mathrm{CD}_{3}$-iron complexes $\left(\mathrm{CpFe}(\mathrm{CO}) \mathrm{L}\left(\mathrm{CD}_{3}\right)\right.$ and $\left.\mathrm{CpFeL}_{2}\left(\mathrm{CD}_{3}\right)\right)$ were obtained. These results obviously show that $\mathrm{C}-\mathrm{C}$ bond in acetonitrile is cleaved in this reaction. In order to check whether the silyl group on the iron plays an important role to cleave the $\mathrm{C}-\mathrm{C}$ bond in acetonitrile, $\mathrm{CpFe}(\mathrm{CO})_{2} \mathrm{Me}, \mathrm{CpFe}(\mathrm{CO})_{2}\left(\mathrm{GeMe}_{3}\right)$, and $\mathrm{CpFe}(\mathrm{CO})_{2}\left(\mathrm{SnMe}_{3}\right)$ were used in place of $\mathrm{CpFe}(\mathrm{CO})_{2}\left(\mathrm{SiMe}_{3}\right)$. No $\mathrm{C}-\mathrm{CN}$ bond cleavage reaction took place, indicating that the silyl ligand on the iron is inevitable to cleave $\mathrm{C}-\mathrm{CN}$ bond in acetonitrile [18].
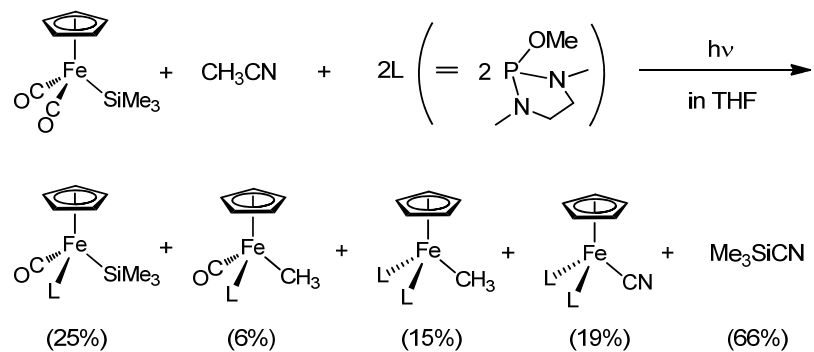
Similar silyl-assisted nitrile $\mathrm{C}-\mathrm{C}$ bond cleavage was reported independently by Bergman, Brookhart and co-workers using Rh [22] and Ir [23] complexes. Later, Hashimoto et al. [24] and Tobiso et al. [25] and their co-workers reported this type of silyl-assisted nitrile $\mathrm{C}-\mathrm{C}$ bond cleavage.

\section{Theoretical approach}

In order to elucidate the role of a silyl group in the iron complex toward C-C bond activation of acetonitrile, DFT calculations were performed. It is expected that at first the irradiation of the coordinatively saturated $\mathrm{CpFe}(\mathrm{CO})_{2}\left(\mathrm{SiMe}_{3}\right)$ will lead to the dissociation of one $\mathrm{CO}$ ligand to form 16e species $\mathrm{CpFe}(\mathrm{CO})\left(\mathrm{SiMe}_{3}\right)$ (A). The direct $\mathrm{C}-\mathrm{C}$ bond oxidative addition of acetonitrile to the $16 \mathrm{e}$ species is less likely to happen, because this reaction requires a very high activation barrier of ca. $53 \mathrm{kcal} / \mathrm{mol}$. Several DFT calculations could find a plausible reaction path which is shown in Figure 1 [18].

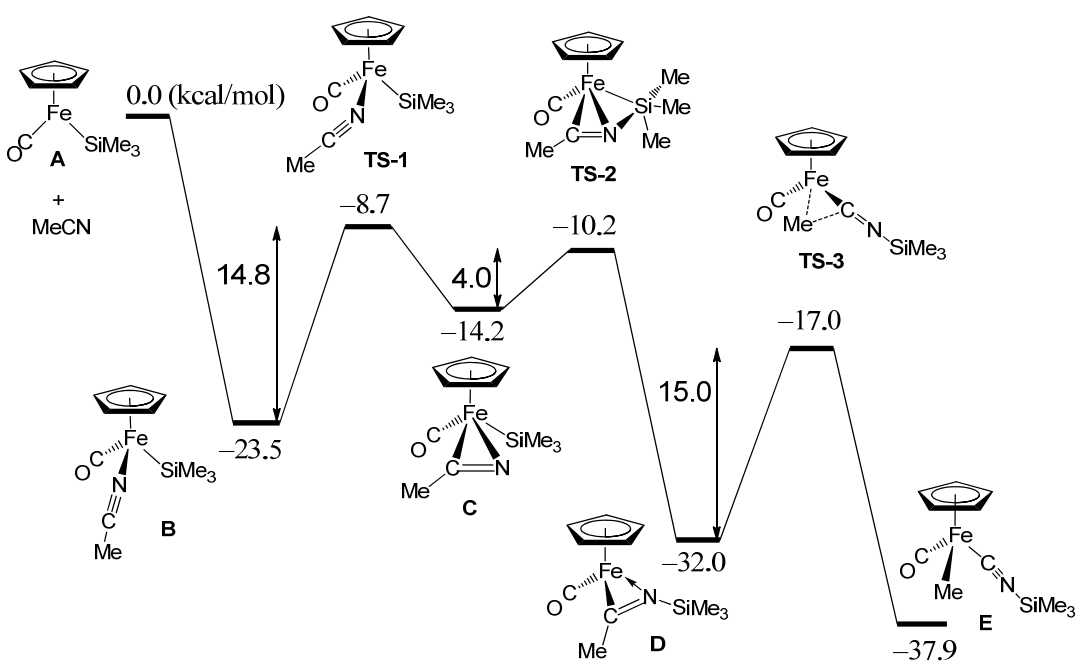

Figure 1: Energy profiles of the reaction of $\mathrm{CpFe}(\mathrm{CO})\left(\mathrm{SiMe}_{3}\right)$ with $\mathrm{MeCN}$ (kcal.mol).

The reaction of $\mathbf{A}$ with $\mathrm{MeCN}$ forms $\mathbf{B}$ with the end-on coordination of acetonitrile with releasing $23.5 \mathrm{kcal} / \mathrm{mol}$. Then, $\mathbf{B}$ is converted into the $\mathrm{CN} \pi$ coordinated species $\mathbf{C}$. This process takes place through a transition state (TS-1) with the activation energy of $14.8 \mathrm{kcal} / \mathrm{mol}$. In $\mathbf{C}$, the migration of the silyl group from $\mathrm{Fe}$ to nitrile nitrogen is possible. The calculations showed that this requires only a small activation energy of $4.0 \mathrm{kcal} / \mathrm{mol}(\mathbf{C}$ to TS-2). From TS-2, a somewhat stable imino complex with the coordination of a nitrogen lone pair to the $\mathrm{Fe}$ atom, $\mathbf{D}$, is formed. If the methyl group of the imino ligand migrates to the iron atom, the methyl iron complex (E) could be formed. It has been found 
that a distortion in $\mathbf{D}$ that breaks the Fe-N bond leads to the transition state TS-3. This process requires an activation energy of $15.0 \mathrm{kcal} / \mathrm{mol}$. The product of this step, $\mathbf{E}$, is $5.9 \mathrm{kcal} / \mathrm{mol}$ more stable than $\mathbf{D}$, which is presumably due to the presence of a strong Fe-C bond.

The reaction profile in Scheme 1 well explains the rupture of the acetonitrile $\mathrm{C}-\mathrm{C}$ bond by the $\mathrm{Fe}$ (II) complex. The highest activation barrier of $15 \mathrm{kcal} / \mathrm{mol}$ is well within the reach of a feasible chemical reaction. Once $\mathbf{E}$ is formed, the formation of $\mathrm{CpFe}(\mathrm{CO}) \mathrm{LMe}$ can be easily achieved by a silylisocyanide/L exchange reaction. The trimethylsilyl isocyanide dissociated from $\mathbf{E}$ may isomerize to trimethylsilyl cyanide. Theoretical calculation suggests that the cyanide is more stable than the isocyanide. This is in accord with the experimental fact that trimethylsilyl cyanide is thermodynamically more favorable [26].

\section{Catalytic C-CN bond cleavage of acetonitrile}

In order to establish a catalytic cycle, photoreaction of a THF solution containing an equimolar amount of $\mathrm{Et}_{3} \mathrm{SiH}$ and $\mathrm{MeCN}$ in the presence of a catalytic amount of $\mathrm{CpFe}(\mathrm{CO})_{2}\left(\mathrm{SiMe}_{3}\right)(2 \mathrm{~mol} \%)$ was examined. The main Si-containing product was $\mathrm{Et}_{3} \mathrm{SiCN}$. The yield based on $\mathrm{Et}_{3} \mathrm{SiH}$ used was $45 \%(\mathrm{TON}=23)$. The results show the $\mathrm{C}-\mathrm{C}$ bond in $\mathrm{MeCN}$ is cleaved catalytically.

Table 1: Catalytic activities of various iron complexes. ${ }^{\mathrm{a}}$

\begin{tabular}{llr} 
& $\mathrm{Et}_{3} \mathrm{SiH}+\mathrm{H}_{3} \mathrm{C}-\mathrm{CN} \underset{\mathrm{THF}, \mathrm{h} v}{\stackrel{\text { catalyst }}{\longrightarrow}} \mathrm{Et}_{3} \mathrm{SiCN}+\mathrm{CH}_{4}$ \\
\hline \multirow{2}{*}{ Entry } & Catalyst & $\mathrm{TON}^{\mathrm{b}}$ \\
\hline 1 & $\mathrm{Cp}(\mathrm{CO})_{2} \mathrm{Fe}\left(\mathrm{SiMe}_{3}\right)$ & 22.5 \\
2 & $\mathrm{Cp}(\mathrm{CO})_{2} \mathrm{Fe}($ benzyl $)$ & 21.3 \\
3 & $\mathrm{Cp}(\mathrm{CO})_{2} \mathrm{FeMe}$ & 36.0 \\
4 & $\mathrm{Cp}(\mathrm{CO})_{2} \mathrm{FeCl}$ & 0.6 \\
5 & $\mathrm{Cp}(\mathrm{CO})_{2} \mathrm{FeI}$ & 2.0 \\
6 & $\left(\mathrm{C}_{5} \mathrm{MeH}_{4}\right)(\mathrm{CO})_{2} \mathrm{FeMe}$ & 32.5 \\
7 & $\left(\mathrm{C}_{5} \mathrm{Me}_{4} \mathrm{H}\right)(\mathrm{CO})_{2} \mathrm{FeMe}$ & 5.7 \\
8 & $\left(\mathrm{C}_{5} \mathrm{Me}_{5}\right)(\mathrm{CO})_{2} \mathrm{FeMe}$ & 4.3 \\
9 & $\left(\mathrm{C}_{5} \mathrm{H}_{4} \mathrm{SiMe}\right)_{3}(\mathrm{CO})_{2} \mathrm{FeMe}$ & 26.4 \\
10 & $\left(\mathrm{C}_{5} \mathrm{H}_{4} \mathrm{SiMe}\right)(\mathrm{CO})_{2} \mathrm{FeI}$ & 2.0 \\
11 & $\left(\mathrm{C}_{5} \mathrm{H}_{4} \mathrm{II}(\mathrm{CO})_{2} \mathrm{FeMe}\right.$ & 12.6 \\
12 & $\left(\mathrm{C}_{5} \mathrm{H}_{4}\left\{\mathrm{P}(\mathrm{O})(\mathrm{OMe})_{2}\right\}\right)(\mathrm{CO})_{2} \mathrm{FeMe}$ & 9.8 \\
\hline
\end{tabular}

a Reactions were carried out at room temperature for $24 \mathrm{~h}$ under photoirradiation by using catallyst $(0.52 \mathrm{mmol}), \mathrm{Et}_{3} \mathrm{SiH}(26.00 \mathrm{mmol})$, and THF $(5.00 \mathrm{~mL})$ in acetonitrile $(13.6 \mathrm{~mL}, 260.00 \mathrm{mmol})$. ${ }^{\mathrm{b}}$ Determined by $\mathrm{GC}$ with toluene as internal standard.

Next, the effect of a ligand at the Fe center on the catalytic activity was examined. For $\mathrm{CpFe}(\mathrm{CO})_{2} \mathrm{R}$ the methyl complex showed better activity than the 
silyl, benzyl, halo complexes. For $\left(\mathrm{C}_{5} \mathrm{R}_{5}\right) \mathrm{Fe}(\mathrm{CO})_{2} \mathrm{Me}$ introduction of substituents into the $\mathrm{Cp}$ ring reduced the catalytic activity. therefore, $\mathrm{CpFe}(\mathrm{CO})_{2} \mathrm{Me}$ showed the best catalytic activity among complexes in Table 1 . The catalytic activities of the related methyl complexes of $\mathrm{Mo}$ and $\mathrm{W}, \mathrm{CpM}(\mathrm{CO})_{3} \mathrm{Me}(\mathrm{M}=\mathrm{Mo}, \mathrm{W})$, were sluggish.

\section{Catalytic C-CN bond cleavage of organonitriles other than acetonitrile}

To see the scope and limitation of catalytic activity of $\mathrm{CpFe}(\mathrm{CO})_{2} \mathrm{Me}$ for $\mathrm{C}-\mathrm{CN}$ bond cleavage, reactions with several organonitriles other than acetonitrile were examined. Table 2 summarizes the results. Propionitrile (EtCN) was converted into $\mathrm{Et}_{3} \mathrm{SiCN}$ in $73 \%$ yield (TON: 18.2) (Table 2, entry 1). Isobutyronitrile $\left({ }^{i} \mathrm{PrCN}\right)$ and malononitrile $\left(\mathrm{NCCH}_{2} \mathrm{CN}\right)$ were poorly converted (Table 2 , entries 2, 3). However, succinonitrile $\left(\mathrm{NCCH}_{2} \mathrm{CH}_{2} \mathrm{CN}\right)$ was converted as much as propionitrile $(65 \%$ yield, $\mathrm{TON}=16.3$; Table 2 , entry 4$)$.

Organonitriles in entries 5-10 were resistant to the C-CN bond cleavage in the reaction conditions (Table 2, entries 5-11). These results indicate that an electron-withdrawing, bulky, or coordination-feasible substituent on a carbon adjacent to the $\mathrm{CN}$ group is unfavorable for the $\mathrm{C}-\mathrm{CN}$ bond cleavage.

Table 2: $\quad$ R-CN bond cleavage reactions of organonitriles. ${ }^{\text {a }}$

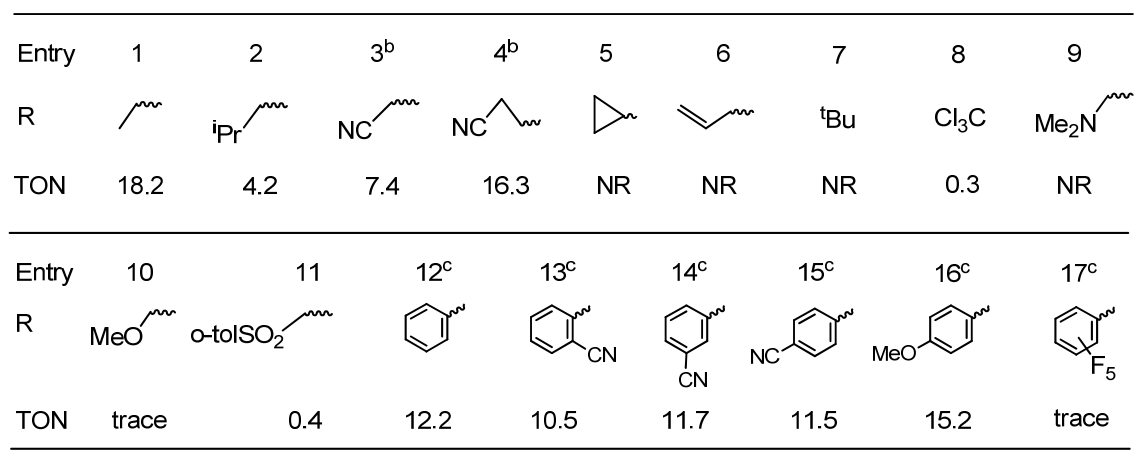

a Catalyst $(0.20 \mathrm{mmol}), \mathrm{Et}_{3} \mathrm{SiH}(5.00 \mathrm{mmol}), \mathrm{THF}(0.40 \mathrm{~mL})$, nitrile compound $(50.00 \mathrm{mmol}) .{ }^{\mathrm{b}}$ Nitrile $(2.50 \mathrm{mmol}), \mathrm{THF}(1.30 \mathrm{~mL}) .{ }^{\mathrm{c}}$ Catalyst $(0.20 \mathrm{mmol}), \mathrm{Et}_{3} \mathrm{SiH}(5.00 \mathrm{mmol}), \mathrm{THF}(8.00 \mathrm{~mL})$, nitrile $(5.00 \mathrm{mmol}) .{ }^{\mathrm{d}}$ Determined by GC with toluene as internal standard.

For aryl nitriles, the C-CN bonds were cleaved with TONs of about 10 (Table 2, entries 12-15). The TON for phthalonitrile is slightly lower (Table 2, entry 13) than that for benzonitrile, which may be due to the presence of an electronwithdrawing group in the ortho position. The TON for $p$-methoxybenzonitrile is slightly higher than for benxonitrile (Table 2, entry 16), which may be due to the electron-releasing OMe group. The $\mathrm{C}-\mathrm{CN}$ bond was hardly cleaved for pentafluorobenzonitrile (table 2, entry 17), possibly due to strongly electronegative nature of $\mathrm{F}$. 


\section{Consideration of catalytic cycle}

A plausible catalytic cycle is shown in Figure 2 for the reaction of $\mathrm{MeCN}$ with $\mathrm{Et}_{3} \mathrm{SiH}$ in the presence of $\mathrm{CpFe}(\mathrm{CO})_{2} \mathrm{Me}$ as a catalyst precursor. One $\mathrm{CO}$ ligand in the precursor is released by photolysis to give $\mathrm{CpFe}(\mathrm{CO}) \mathrm{Me}$, which reacts with $\mathrm{Et}_{3} \mathrm{SiH}$ to give $\mathrm{CpFe}(\mathrm{CO})(\mathrm{Me})(\mathrm{H})\left(\mathrm{SiEt}_{3}\right)$. This process seems plausible because oxidative addition of an $\mathrm{Si}-\mathrm{H}$ bond to a 16e-species of $\mathrm{Fe}$ was reported to give, for example, $\mathrm{CpFe}(\mathrm{CO})(\mathrm{H})\left(\mathrm{SiEt}_{3}\right)_{2}$ [27]. The subsequent reductive elimination of $\mathrm{CH}_{4}$ yields $\mathrm{CpFe}(\mathrm{CO})\left(\mathrm{SiEt}_{3}\right)$. As $\mathrm{SiEt}_{3} \mathrm{Me}$ was not observed at all in this system, reductive elimination of $\mathrm{CH}_{4}$ from $\mathrm{CpFe}(\mathrm{CO}) \mathrm{Me}(\mathrm{H})\left(\mathrm{SiEt}_{3}\right)$ seems to precede that of $\mathrm{Et}_{3} \mathrm{SiMe}$. The $16 \mathrm{e}$ species thus formed reacts with $\mathrm{MeCN}$ to give ultimately $\mathrm{CpFe}(\mathrm{CO})(\mathrm{Me})\left(\eta^{1}-\mathrm{CNSiEt}_{3}\right)$. The reaction sequences have been demonstrated theoretically (Figure 1) [18]. Dissociation of $\mathrm{Et}_{3} \mathrm{SiNC}_{\text {generates }}$ $\mathrm{CpFe}(\mathrm{CO}) \mathrm{Me}$ to complete the catalytic cycle. The released $\mathrm{Et}_{3} \mathrm{SiNC}$ isomerizes to thermodynamically stable $\mathrm{Et}_{3} \mathrm{SiCN}$.

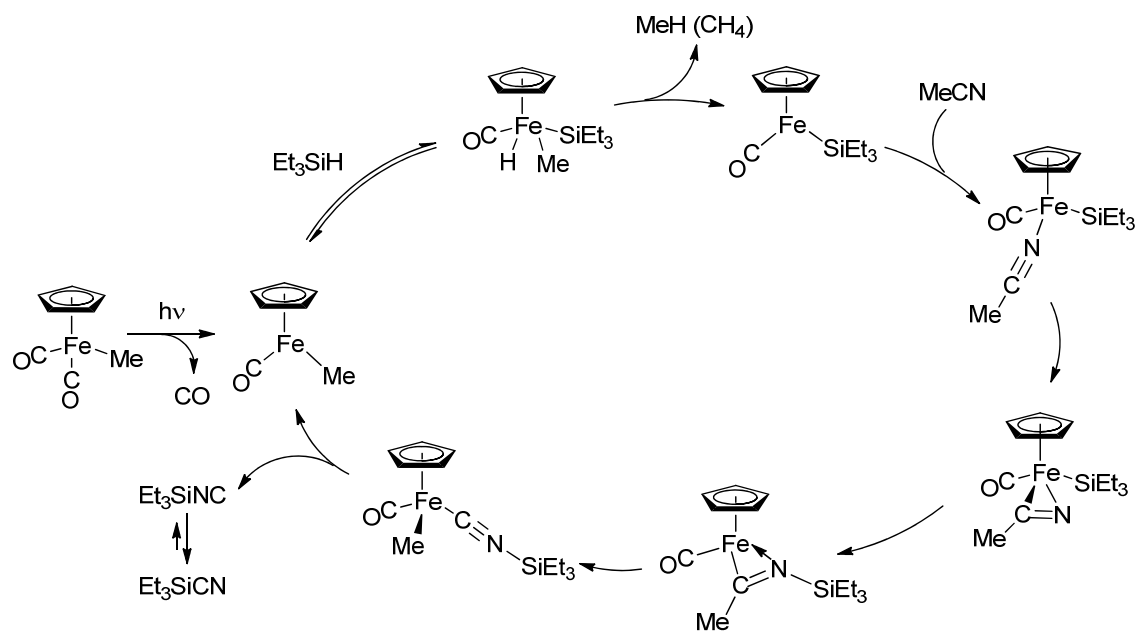

Figure 2: $\quad$ Proposed catalytic cycle.

According to the catalytic cycle shown in Figure 2, $\mathrm{CpFe}(\mathrm{CO})\left(\mathrm{SiEt}_{3}\right)$ can react with both $\mathrm{MeCN}$ and $\mathrm{Et}_{3} \mathrm{SiH}$. The former reaction seems dominant, but the latter is not negligible. If the reaction of $\mathrm{CpFe}(\mathrm{CO})\left(\mathrm{SiEt}_{3}\right)$ with $\mathrm{Et}_{3} \mathrm{SiH}$ is suppressed, the catalytic cycle is expected to work more effectively. Thus the reaction on changing the molar ratio of $\mathrm{Et}_{3} \mathrm{SiH}$ and $\mathrm{MeCN}$ was examined. Reaction of $\mathrm{Et}_{3} \mathrm{SiH}$ with a 10 -fold molar excess of $\mathrm{MeCN}$ in the presence of 0.83 $\mathrm{mol} \% \mathrm{CpFe}(\mathrm{CO})_{2} \mathrm{Me}$ under photolysis for $24 \mathrm{~h}$ at $50^{\circ} \mathrm{C}$ produced $99 \%$ yield of $\mathrm{Et}_{3} \mathrm{SiCN}$ base on $\mathrm{Et}_{3} \mathrm{SiH}$ (TON: 118). The TON increased with the photoirradiation time (48 h: 156, $96 \mathrm{~h}: 197)$. The highest TON (251) was obtained when $\mathrm{Et}_{3} \mathrm{SiH}$ and a 10-fold molar excess of $\mathrm{MeCN}$ were photolyzed for 
1 week at $50^{\circ} \mathrm{C}$ in the presence of $0.2 \mathrm{~mol} \%$ of $\mathrm{CpFe}(\mathrm{CO})_{2} \mathrm{Me}$. Compared with $\mathrm{Pd}[17]$ and $\mathrm{Rh}[22]$ systems, this catalytic system is very effective.

\section{$7 \quad \mathrm{~N}-\mathrm{CN}$ bond cleavage of cyanamides}

New reaction pattern of $\mathrm{C}-\mathrm{CN}$ bond cleavage of organonitriles promoted by a silyl-iron complex has been described above. The essence of the reaction mechanism is silyl migration from $\mathrm{Fe}$ to the nitrogen in nitrile which is $\eta^{2}$ coordinated through $\mathrm{C} \equiv \mathrm{N} \pi$-bond. This migration causes $\mathrm{C}$ - $\mathrm{CN}$ bond cleavage. The replacement of the R group in $\mathrm{RCN}$ (organonitrile) by an $\mathrm{NR}_{2}$ group yields cyanamide described as $\mathrm{R}_{2} \mathrm{NCN}$. Therefore, there is a possibility of N-CN bond cleavage of cyanamide in the reaction with a transition metal complex bearing a silyl ligand.

The $\mathrm{R}_{2} \mathrm{~N}-\mathrm{CN}$ bond is known to be strong and not broken readily. For example, the N-CN bond length in $\mathrm{Me}\left(p-\mathrm{C}_{6} \mathrm{H}_{4} \mathrm{Cl}\right) \mathrm{N}-\mathrm{CN}$ is reported to be 1.331 $\AA$, which lies just between that of a normal N-C single bond (1.47 $\AA$ ) and that of an $\mathrm{N}=\mathrm{C}$ double bond $(1.27 \AA)$ [28]. The von Braun reaction is the only reaction known to date to cleave $\mathrm{R}_{2} \mathrm{~N}-\mathrm{CN}$ bond. However, it requires harsh reaction conditions (strong acid or base conditions). Reactions of cyanamides with a transition metal complex bearing a silyl ligand were examined both in hopes of $\mathrm{N}-\mathrm{CN}$ bond cleavage and with worrying about coordination of cyanamide to the 16e Fe species, $\mathrm{Cp}(\mathrm{CO}) \mathrm{Fe}\left(\mathrm{SiEt}_{3}\right)$, through a lone pair of electrons on the amino nitrogen causing disappearance of the activity of the iron complex toward $\mathrm{R}_{2} \mathrm{~N}$ $\mathrm{CN}$ bond cleavage.

Table 3: $\quad$ Photoreaction of cyanamides with $\mathrm{CpFe}(\mathrm{CO})_{2}\left(\mathrm{SiEt}_{3}\right)$.

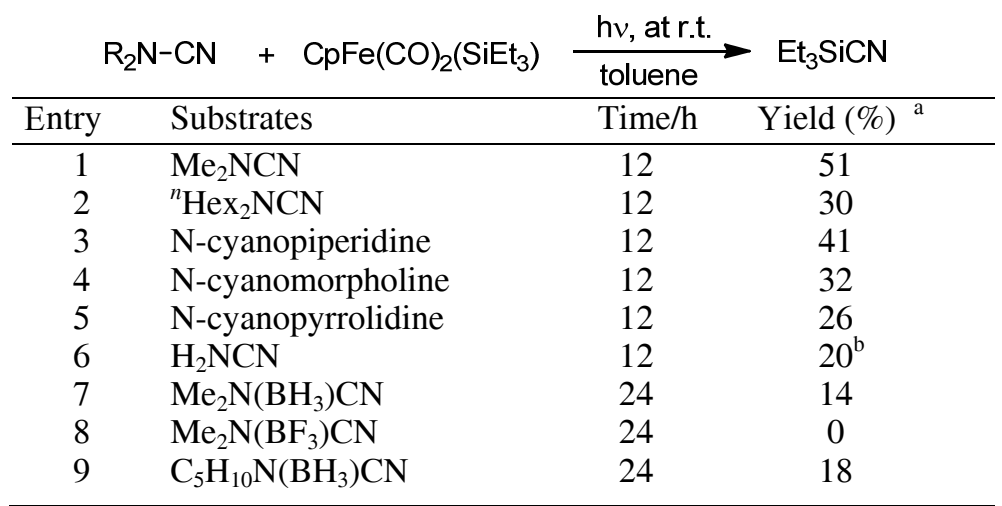

a Yield of $\mathrm{Et}_{3} \mathrm{SiCN}$ obtained by GC. ${ }^{\mathrm{b}}$ In 1,2-dichloroethane

A solution of an equimolar amount of dimethylcyanamide and $\mathrm{CpFe}(\mathrm{CO})_{2}\left(\mathrm{SiEt}_{3}\right)(\mathbf{1})$ in toluene was photoirradiated at room temperature for 12 h. The ${ }^{1} \mathrm{H}$ NMR spectrum and the GC analysis of the reaction mixture showed formation of $\mathrm{Et}_{3} \mathrm{SiCN}$. The yield was $51 \%$ (Table 3, entry 1), showing that the 
$\mathrm{Me}_{2} \mathrm{~N}-\mathrm{CN}$ bond cleavage could be attained at room temperature using a silyl-iron complex.

Results of reactions with other cyanamides are presented in Table 3. Although the yields of $\mathrm{Et}_{3} \mathrm{SiCN}$ are less than $50 \%$, these $\mathrm{N}-\mathrm{CN}$ bonds are cleaved (entries 2-6). The reaction of $\mathrm{H}_{2} \mathrm{NCN}$ is noteworthy (entry 6). The $\mathrm{H}_{2} \mathrm{~N}-\mathrm{CN}$ bond has a double bond character because $\mathrm{H}_{2} \mathrm{~N}-\mathrm{CN}$ (cyanamide) is a tautomer of $\mathrm{HN}=\mathrm{C}=\mathrm{NH}$ (carbodiimide). Therefore $\mathrm{H}_{2} \mathrm{~N}-\mathrm{CN}$ bond is stronger than other $\mathrm{R}_{2} \mathrm{~N}$ $\mathrm{CN}$. The first $\mathrm{H}_{2} \mathrm{~N}-\mathrm{CN}$ bond cleavage is attainable in these reaction conditions, although the efficiency remains insufficient.

Derivation of cyanamide into the borane adduct at the amino nitrogen, $\mathrm{R}_{2} \mathrm{~N}\left(\mathrm{BX}_{3}\right) \mathrm{CN}(\mathrm{X}=\mathrm{H}, \mathrm{F})$ [29], might engender more effective $\mathrm{R}_{2} \mathrm{~N}-\mathrm{CN}$ bond cleavage because of masking of the lone pair electrons on the amino nitrogen. The results (entries 7-9) showed that the introduction of borane into cyanamide did not facilitate $\mathrm{R}_{2} \mathrm{~N}-\mathrm{CN}$ bond cleavage; instead, it reduced the activity, presumably because of steric hindrance.

Reaction sequences resembling those in Figure 2 are expected for the reaction of 1 with cyanamide. Isolation of the $\mathrm{N}$-silylated $\eta^{2}$-amidino iron intermediate was attempted, but the reaction of 1 with $\mathrm{Me}_{2} \mathrm{NCN}$ was unsuccessful. However, reactions with $\mathrm{Me}_{2} \mathrm{NCN}$ of $\left(\mathrm{C}_{5} \mathrm{R}_{5}\right) \mathrm{Fe}(\mathrm{CO})(\mathrm{py})\left(\mathrm{SiR}^{\prime} \mathrm{R}^{\prime}{ }_{2}\right)$ (py = pyridine), considered as a synthon of a $16 \mathrm{e}$ complex $\left(\mathrm{C}_{5} \mathrm{R}_{5}\right) \mathrm{Fe}(\mathrm{CO})\left(\mathrm{SiR}^{\prime} \mathrm{R}^{\prime \prime}{ }_{2}\right)$, led to isolation of $\mathrm{N}$-silylated $\eta^{2}$-amidino iron complexes (eq. (3)). Heating a solution containing 2 and $\mathrm{Me}_{2} \mathrm{NCN}$ in benzene at $50{ }^{\circ} \mathrm{C}$ for $10 \mathrm{~h}$ yielded $\mathbf{3}$ quantitatively according to the NMR measurements, but the isolation as a solid was failed. In contrast, a reaction of $\mathbf{4}$ with $\mathrm{Me}_{2} \mathrm{NCN}$ yielded $\mathbf{5}$, which could be isolated as dark-red powders in $85 \%$ yield. The unprecedented $\eta^{2}$-amidino complex was confirmed using X-ray analysis (Figure 3). The iron takes a distorted threelegged piano-stool structure with an $\eta^{2}$-amidino fragment. The bond distance of N1-C2 $(1.327 \AA)$ is shorter than that of a typical N-C single bond (e.g., C3-N1 = $1.455 \AA, \mathrm{C} 4-\mathrm{N} 1=1.458 \AA$ ), and is rather similar to that of an $\mathrm{N}=\mathrm{C}$ double bond (e.g., $\mathrm{N} 2-\mathrm{C} 2=1.303 \AA$ ). The sum of angles around $\mathrm{N} 1$ is $359.9^{\circ}$. These structural characters are consistent with $\mathrm{sp}^{2}$ hybridization of N1. The C3-N1-C2$\mathrm{N} 2$ fragment is nearly planar with a torsion angle of $2.6(4)^{\circ}$. Both ${ }^{1} \mathrm{H}$ and ${ }^{13} \mathrm{C}$ NMR spectra show that the structure in a solid state is maintained in solution. Two $\mathrm{NCH}_{3}$ resonances were observed at room temperature in ${ }^{1} \mathrm{H}$ and ${ }^{13} \mathrm{C} \mathrm{NMR}$, reflecting that the $\mathrm{C} 2-\mathrm{N} 1$ bond does not rotate freely at room temperature.

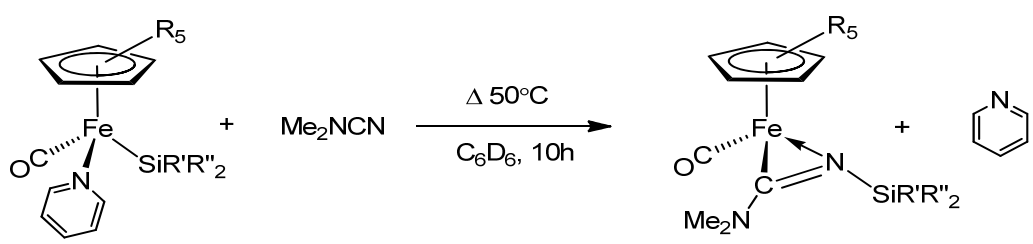

$$
\begin{aligned}
& R=H ; R^{\prime}, R^{\prime \prime}=E t \quad 2 \\
& R=M e ; R^{\prime}=P h ; R^{\prime \prime}=M e \quad 4
\end{aligned}
$$

$\mathrm{N}$-silylated $\eta^{2}$-amidino iron complex

$$
\begin{aligned}
& R=H ; R^{\prime}, R^{\prime \prime}=E t 3 \\
& R=M e ; R^{\prime}=P h ; R^{\prime \prime}=M e
\end{aligned}
$$




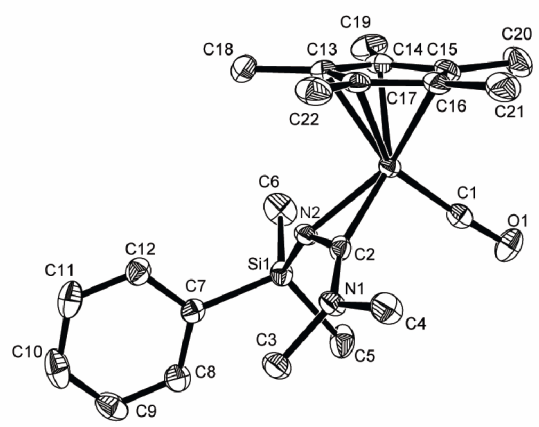

Figure 3: ORTEP drawing of 5. Selected bond distances $(\AA)$ and angles (deg): $\mathrm{N} 1-\mathrm{C} 2=1.327(3) ; \mathrm{N} 2-\mathrm{C} 2=1.303(2) ; \mathrm{C} 2-\mathrm{N} 1-\mathrm{C} 3=$ 123.4(2); C2-N1-C4 = 119.5(2); C3-N1-C4 = 117.0(2).

Complexes $\mathbf{3}$ and $\mathbf{5}$ were subjected to a thermal reaction. Although $\mathbf{5}$ produced a small amount of $\mathrm{PhMe}_{2} \mathrm{SiCN}$ on heating in toluene at $110^{\circ} \mathrm{C}$ for $24 \mathrm{~h}$, 3 gave $\mathrm{Et}_{3} \mathrm{SiCN}$ in $62 \%$ yield on heating in benzene at $70^{\circ} \mathrm{C}$ for $24 \mathrm{~h}$. The results show that an N-silylated $\eta^{2}$-amidino complex is an intermediate in the $\mathrm{N}-\mathrm{CN}$ bond cleavage of cyanamide.

Table 4: Catalytic cleavage under photolysis or heating.

\begin{tabular}{ccccccc}
\multicolumn{3}{c}{$\mathrm{Me}_{2} \mathrm{NCN}+\mathrm{Et}_{3} \mathrm{SiH}$} & \multicolumn{3}{c}{ cat. $\mathbf{6}$ or $\mathbf{7}^{\mathrm{a}}$} & \multicolumn{3}{c}{$\mathrm{Et}_{3} \mathrm{SiCN}$} \\
\hline Entry & Cat. & {$[\mathrm{M}]:[\mathrm{N}]:[\mathrm{Si}]^{b}$} & Condition & $\mathrm{Temp} /{ }^{\circ} \mathrm{C}$ & Time/h & $\mathrm{TON}^{c}$ \\
\hline 1 & $\mathbf{6}$ & $1: 10: 10$ & $\mathrm{~h} v$ & 25 & 24 & 0.4 \\
2 & $\mathbf{7}$ & $1: 10: 10$ & $\mathrm{~h} v$ & 25 & 24 & 1.4 \\
3 & $\mathbf{6}$ & $1: 1: 1$ & $\Delta$ & 80 & 12 & 0 \\
4 & $\mathbf{7}$ & $1: 1: 1$ & $\Delta$ & 100 & 12 & 0.52 \\
$5^{d}$ & $\mathbf{7}$ & $1: 10: 1000$ & $\Delta$ & 100 & 48 & 7.9 \\
$6^{d}$ & $\mathbf{7}$ & $1: 1000: 5000$ & $\Delta$ & 100 & 120 & 32.3 \\
\hline
\end{tabular}

${ }^{a} \mathrm{No} \mathrm{Me}_{2} \mathrm{NCN}$ bond cleavage took place in the absence of 6 or 7 . ${ }^{\mathrm{b}}$ Molar ratio of a transition metal complex, $\mathrm{Me}_{2} \mathrm{NCN}$, and $\mathrm{Et}_{3} \mathrm{SiH}$. ${ }^{\mathrm{c}}$ Calculated from the isolated $\mathrm{Et}_{3} \mathrm{SiCN}$. The values are based on the concentration of a transition metal complex. ${ }^{d}$ In free solvent.

Catalytic N-CN bond cleavage of cyanamides has been attempted. Table 4 shows the results of reactions of $\mathrm{Me}_{2} \mathrm{NCN}$ and $\mathrm{Et}_{3} \mathrm{SiH}$ in the presence of a catalytic amount of $\mathrm{CpFe}(\mathrm{CO})_{2} \mathrm{Me}$ or $\mathrm{CpMo}(\mathrm{CO})_{3} \mathrm{Me}$. Entry 1 shows that the $\mathrm{Fe}$ complex does not work as a catalyst, whereas the Mo complex does under photoirradiation conditions (Table 4, entry 2). The Mo complex shows catalytic activity even under thermal conditions (Table 4, entries 4-6). These results show the first example of catalytic N-CN bond cleavage of cyanamides by a transition metal complex. 


\section{Conclusions}

It was found that a $16 \mathrm{e}$ species bearing a transition metal-silyl bond, such as $\mathrm{CpFe}(\mathrm{CO})\left(\mathrm{SiR}_{3}\right)$ and $\mathrm{CpMo}(\mathrm{CO})_{2}\left(\mathrm{SiR}_{3}\right)$, serves as a real catalyst for $\mathrm{C}-\mathrm{CN}$ and $\mathrm{N}-\mathrm{CN}$ bond cleavage in organonitriles and cyanamides, respectively. Silyl migration from a transition metal to the nitrogen of the nitrile group in RCN and $\mathrm{R}_{2} \mathrm{NCN}$ coordinating to the transition metal in $\eta^{2}$-fashion leads to the strong $\mathrm{C}$ $\mathrm{CN}$ and $\mathrm{N}-\mathrm{CN}$ bond cleavage.

\section{References}

[1] a) Crabtree, R. H., The organometallic chemistry of alkanes. Chem. Rev. 85, pp. 245-269, 1985. b) Rybtchinski, B. \& Milstein, D., Metal insertion into C-C bonds in solution. Angew. Chem., Int. Ed., 38, pp. 870-883, 1999. c) Jun, C.-H., Transition metal-catalyzed carbon-carbon bond activation. Chem. Soc. Rev., 33, pp. 610-618, 2004.

[2] Burmeister, J. L. \& Edwards, L. M., Carbon-carbon bond cleavage via oxidative addition: Reaction of tetrakis(triphenylphosphine)platinum( 0 ) with 1,1,1-tricyanoethane. J. Chem. Soc. A., pp. 1663-1666, 1971.

[3] Gerlach, D. H., Kane, A. R., Parshall, G. W., Jesson, J. P. \& Muetterties, E. L., Reactivity of trialkylphosphine complexes of platinum(0). J. Am. Chem. Soc., 93, pp. 3543-3544, 1971.

[4] Cassar, L., A new nickel-catalyzed synthesis of aromatic nitriles. $J$. Organomet. Chem., 54, pp. C57-C58, 1973.

[5] Parshall, G. W., $\sigma$-Aryl compounds of nickel, palladium, and platinum. Synthesis and bonding studies. J. Am. Chem. Soc., 96, pp. 2360-2366, 1974.

[6] Favero, G., Morvillo, A. \& Turco, A., Oxidative addition of alkanenitriles to nickel( 0 ) complexes via $\pi$-intermediates. J. Organomet. Chem., 241, pp. 251-257, 1983.

[7] Bianchini, C., Masi, D., Meli, A. \& Sabat, M., Reactions of ethyl cyanoformate with $\left(\mathrm{np}_{3}\right) \mathrm{Ni},\left(\mathrm{np}_{3}\right) \mathrm{CoH}\left[\mathrm{np}_{3}=\mathrm{N}\left(\mathrm{CH}_{2} \mathrm{CH}_{2} \mathrm{PPh}_{2}\right)_{3}\right]$, and (triphos) $\mathrm{Ni}$ [triphos $=\mathrm{MeC}\left(\mathrm{CH}_{2} \mathrm{PPh}_{2}\right)_{3}$ ]. Crystal structures of the ethoxycarbonyl complexes $\quad\left[\left(\mathrm{np}_{3}\right) \mathrm{Ni}\left(\mathrm{CO}_{2} \mathrm{Et}\right)\right] \mathrm{BPh}_{4} \quad$ and (triphos) $\mathrm{Ni}(\mathrm{CN})\left(\mathrm{CO}_{2}\right.$ Et). Organometallics, 5, pp. 1670-1675, 1986.

[8] Abla, M. \& Yamamoto, T., Oxidative addition of C-CN bond to nickel( $(0)$ complex: Synthesis and crystal structures of $\mathrm{Ni}(\mathrm{CN})\left(\mathrm{o}-\mathrm{C}_{6} \mathrm{H}_{4} \mathrm{CN}\right)($ bpy) and $\mathrm{Ni}(\mathrm{CN})\left(\mathrm{p}-\mathrm{C}_{6} \mathrm{H}_{4} \mathrm{CN}\right)(\mathrm{bpy})$. J. Organomet. Chem., 532, pp. 267-270, 1997.

[9] a) Brunkan, N. M., Brestensky, D. M. \& Jones, W. D., Kinetics, thermodynamics, and effect of $\mathrm{BPh}_{3}$ on competitive $\mathrm{C}-\mathrm{C}$ and $\mathrm{C}-\mathrm{H}$ bond activation reactions in the interconversion of allyl cyanide by [No(dippe)]. J. Am. Chem. Soc., 126, pp. 3627-3641, 2004. b) Garcia, J. J., Arevalo, A., Brunkan, N. M. \& Jones, W. D., Cleavage of carbon-carbon bonds in alkyl cyanides using nickel(0). Organometallics, 23, pp. 3997-4002, 2004. 
[10] Liu, Q.-X., Xu, F.-B., Li, Q.-S., Song, H.-B. \& Zhang, Z.-Z., Formation of the fluorescent complexes $\left[(\text { carbene })_{2} \mathrm{M}^{\mathrm{II}}(\mathrm{CN})_{2}\right](\mathrm{M}=\mathrm{Ni}, \mathrm{Pd}, \mathrm{Pt})$ by $\mathrm{C}-\mathrm{C}$ bond cleavage of $\mathrm{CH}_{3} \mathrm{CN}$. Organometallics, 23, pp. 610-614, 2004.

[11] Churchill, D., Shin, J. H., Hascall, T., Hahn, J. M., Bridgewater, B. M. \& Parkin, G., The ansa effect in permethylmolybdenocene chemistry: A $\left[\mathrm{Me}_{2} \mathrm{Si}\right]$ ansa bridge promotes intermolecular $\mathrm{C}-\mathrm{H}$ and $\mathrm{C}-\mathrm{C}$ bond activation. Organometallics, 18, pp. 2403-2406, 1999.

[12] Ozawa, F., Iri, K. \& Yamamoto, A., C-CN bond cleavage under mild conditions promoted by electron-rich cobalt complexes. Chem. Lett., pp. 1707-1710, 1982.

[13] Adam, R., Villiers, C., Ephritikhine, M., Lance, M., Nierlich, M. \& Vigner, J., Synthesis, structure and oxidative addition reactions of triscyclopentadienyluranium(III) nitrile complexes. J. Organomet. Chem., 445, pp. 99-106, 1993.

[14] Marlin, D. S., Olmstead, M. M. \& Mascharak, P. K., Heterolytic cleavage of the $\mathrm{C}-\mathrm{C}$ bond of acetonitrile with simple monomeric $\mathrm{Cu}^{\mathrm{II}}$ complexes: Melding old copper chemistry with new reactivity. Angew. Chem. Int. Ed., 40, pp. 4752-4754, 2001.

[15] Lu, T., Zhuang, X., Li, Y. \& Chen, S., C-C bond cleavage of acetonitrile by a dinuclear copper(II) cryptate. J. Am. Chem. Soc., 126, pp. 4760-4761, 2004.

[16] a) Penney, J. M. \& Miller, J. A., Alkynylation of benzonitriles via nickel catalyzed C-C bond activation. Tetrahedron Lett., 45, pp. 4989-4992, 2004. b) Chaumonnot, A., Lamy, F., Sabo-Etienne, S., Donnadieu, B., Chaudret, B., Barthelat, J.-C. \& Galland, J.-C., Catalytic isomerization of cyanoolefins involved in the adiponitrile process. C-CN bond cleavage and structure of the nickel $\pi$-allyl cyanide complex $\mathrm{Ni}\left(\eta^{3}-1-\mathrm{Me}-\right.$ $\left.\mathrm{C}_{3} \mathrm{H}_{4}\right)(\mathrm{CN})(\mathrm{dppb})$. Organometallics, 23, pp. 3363-3365, 2004. c) Wilting, J., Müller, C., Hewat, A. C., Ellis, D. D., Tooke, D. M., Spek, A. L. \& Vogt, D., Nickel-catalyzed isomerization of 2-methyl-3-butenenitrile. Organometallics, 24, pp. 13-15, 2005. d) Nakao, Y., Yukawa, T., Hirata, Y., Oda, S., Satoh, J. \& Hiyama, T., Allylcyanation of alkynes: Regio- and stereoselective access to functionalized di- or trisubstituted acrylonitriles. J. Am. Chem. Soc., 128, pp. 7116-7117, 2006.

[17] a) Murahashi, S., Naota, T. \& Nakajima, N., Palladium-catalyzed decarbonylation of acyl cyanides. J. Org. Chem., 51, pp. 898-901, 1986. b) Luo, F.-H., Chu, C.-I. \& Cheng, C.-H., Nitrile-group transfer from solvents to aryl halides. Novel carbon-carbon bond formation and cleavage mediated by palladium and zinc species. Organometallics, 17, pp. 1025-1030, 1998. c) Nishihara, Y., Inoue, Y., Itazaki, M. \& Takagi, K., Palladium-catalyzed cyanoesterification of norbornenes with cyanoformates via the NC-PdCOOR ( $\mathrm{R}=\mathrm{Me}$ and Et) intermediate. Org. Lett., 7, pp. 2639-2641, 2005.

[18] Nakazawa, H., Kawasaki, T., Miyoshi, K., Suresh, C. H. \& Koga, N., C-C bond cleavage of acetonitrile by a carbonyl iron complex with a silyl ligand. Organometallics, 23, pp. 117-126, 2004. 
[19] Nakazawa, H., Kamata, K. \& Itazaki, M., Catalytic C-C bond cleavage and $\mathrm{C}$-Si bond formation in reaction of $\mathrm{RCN}$ with $\mathrm{Et}_{3} \mathrm{SiH}$ promoted by an iron complex. Chem. Commun., pp. 4004-4006, 2005.

[20] Nakazawa, H., Itazaki, M., Kamata, K. \& Ueda, K., Iron-complexcatalyzed C-C bond cleavage of organonitriles: Catalytic metathesis reaction between $\mathrm{H}-\mathrm{Si}$ and $\mathrm{R}-\mathrm{CN}$ bonds to afford $\mathrm{R}-\mathrm{H}$ and $\mathrm{Si}-\mathrm{CN}$ bonds. Chem. Asian. J., 2, pp. 882-888, 2007.

[21] Fukumoto, K., Oya, T., Itazaki, M. \& Nakazawa, H., N-CN bond cleavage of cyanamides by a transition-metal complex. J. Am. Chem. Soc., 131, pp. 38-39, 2009.

[22] Taw, F. L., Mueller, A. H., Bergman, R. G. \& Brookhart, M., A mechanistic investigation of the carbon-carbon bond cleavage of aryl and alkyl cyanides using a cationic Rh(III) silyl complex. J. Am. Chem. Soc., 125, pp. 9808-9813, 2003.

[23] Klei, S. R., Tilley, T. D. \& Bergman, R. G., Stoichiometric and catalytic behavior of cationic silyl and silylene complexes. Organometallics, 21, pp. 4648-4661, 2002.

[24] Hashimoto, H., Matsuda, A. \& Tobita, H., Reactions of a silyl(silylene)iron complex with nitriles: Carbon-carbon bond cleavage of nitriles by the transiently generated disilanyliron(II) intermediate. Organometallics, 25, pp. 472-476, 2006.

[25] Tobisu, M., Kita, Y. \& Chatani, N., Rh(I)-catalyzed silylation of aryl and alkenyl cyanides involving the cleavage of $\mathrm{C}-\mathrm{C}$ and Si-Si bonds. J. Am. Chem. Soc., 128, pp. 8152-8153, 2006.

[26] Seckar, J. A. \& Thayer, J. S., Normal-iso rearrangement in cyanotrialkylsilanes. Inorg. Chem., 15, pp. 501-504, 1976.

[27] Akita, M., Oku, T., Tanaka, M. \& Moro-oka, Y., Oxymethylation of alkyliron complex $\mathrm{CpFe}(\mathrm{CO})_{2} \mathrm{R}$ with hydrostannane and -silane, leading to $\mathrm{RCH}_{2} \mathrm{OH}$ derivatives: related reactions of $\mathrm{CpFe}(\mathrm{CO})(\mathrm{L}) \mathrm{R}$ and $\mathrm{CpFe}(\mathrm{CO})(\mathrm{L}) \mathrm{C}(\mathrm{O}) \mathrm{R}$ type organoiron complexes and the molecular structure of trans-CpFe $(\mathrm{H})(\mathrm{CO})\left(\mathrm{SnPh}_{3}\right)_{2}$. Organometallics, 10, pp. 3080 3089, 1991.

[28] Cunningham, I. D., Light, M. E. \& Hursthouse, M. B., N-(4-chlorophenyl)N-methylcyanamide. Acat Cryst. Sect. C, Cryst. Struct. Commun., 55, pp. 1833-1835, 1999.

[29] Henneike, H. F. \& Drago, R. S., Comparison of the donor properties of dimethylcyanamide and acetonitriles. Inorg. Chem., 7, pp. 1908-1915, 1968. 